\title{
Biologging to examine multiple life stages of an estuarine-dependent fish
}

\author{
Andrew B. Barbour ${ }^{1, *}$, Aaron J. Adams ${ }^{2}$ \\ ${ }^{1}$ School of Forest Resources and Conservation, Program of Fisheries and Aquatic Sciences, 7922 NW 71 st St, \\ University of Florida, Gainesville, Florida 32653, USA \\ ${ }^{2}$ Mote Marine Laboratory, Charlotte Harbor Field Station, PO Box 2197, Pineland, Florida 33945, USA
}

\begin{abstract}
To better understand habitat use through ontogeny, this paper synthesizes 7 yr of biologging research on the adult and juvenile life stages of an estuarine-dependent fish, the common snook Centropomus undecimalis in Charlotte Harbor, Florida, USA. During 3 yr of telemetry research in a putative nursery habitat (mangrove creeks), we resighted $85.4 \%$ of 1924 juvenile snook marked after, and $13.5 \%$ of 2191 juveniles marked prior to, deployment of a telemetry array. During 4 yr of research in spawning habitat (barrier island beaches), we used seine nets and recaptured $5.63 \%$ of 3304 marked adult snook. After analyzing these concurrent data sets, we found significant intra- and interannual site fidelity patterns in both life stages, while documenting movement between juvenile and adult spawning habitats. Additionally, this tag-based approach allowed an investigation of the relative effects of a severe cold event, which reduced apparent survival by 22.6 to $38.3 \%$ for juveniles and 97.8 to $98.5 \%$ for adults. This work presents data within and between life stages that are critical to understanding processes affecting ontogenetic habitat use and connectivity and underscores the importance of incorporating withinstage fidelity and emigration in studies on ontogeny.
\end{abstract}

KEY WORDS: Centropomus undecimalis · Nursery habitat $\cdot$ Spawning habitat $\cdot$ Connectivity $\cdot$ Site fidelity - Emigration - Survival estimation - Disturbance - Metapopulation - Passive integrated transponder · PIT

Resale or republication not permitted without written consent of the publisher

\section{INTRODUCTION}

The life history of many marine fishes is a 3-phase cycle, whereby adults, larvae, and juvenile life stages have different biological requirements and in many cases utilize different habitats. For fishes that use different habitats for each life phase, this 3-phase life cycle decouples reproduction from recruitment of new individuals into the local population. This is especially true for fish taxa with larvae that settle into benthic habitats that are distinct from those of adults (Shulman \& Ogden 1987, Eggleston 1995, Peters et al. 1998, Herzka et al. 2002, Shenker et al. 2002), creating 2 stages within the demersal phase of life his- tory. Examination of the processes affecting each of these life stages, and the connections between life stages, is essential to developing a better understanding of ontogenetic habitat requirements of fishes.

The spatial separation between juvenile nursery habitats and adult spawning habitats is well documented for many marine fish (e.g. northern red snapper Lutjanus campechanus, Cowan et al. 2010; Nassau grouper Epinephelus striatus, Eggleston 1995, Grover et al. 1998, Bolden 2000; common snook Centropomus undecimalis, Adams et al. 2006a, 2009). However, despite such documentation of specific habitats used throughout ontogeny, it remains un- 
known to what degree behavioral use differs among these habitats and life stages for most species. Due to recent advances in biologging technology, we are now able to effectively study multiple ontogenetic habitats and life stages to better understand habitat use patterns, which is critical to developing a more complete picture of fish ontogeny. This information allows a better understanding of the processes that structure fish populations.

In this paper, we synthesized 7 yr of biologging research on an estuarine-dependent fish, the common snook, to highlight patterns in habitat use of juveniles in nursery habitat and adults in spawning habitat. We report new information on habitat use of juvenile snook in nursery habitat, summarize and expand upon results of a previous study on fidelity of adult snook to spawning grounds, document habitat overlap between the 2 life stages, and quantify the effects of a severe cold event (disturbance) on both life stages.

\section{MATERIALS AND METHODS}

\section{Study area}

Charlotte Harbor is a $700 \mathrm{~km}^{2}$ coastal plain estuarine system in subtropical, southwest Florida, USA (Fig. 1; Hammett 1990). Seagrass flats $\left(262 \mathrm{~km}^{2}\right.$, Sargent et al. 1995) and mangrove shorelines (143 $\mathrm{km}^{2}$, L. Kish unpubl. data) are the dominant habitats within the estuary. Three rivers, as well as numerous creeks throughout the drainage, transport large amounts of fresh water into the harbor. The estuary is separated from the Gulf of Mexico by a string of barrier islands, with tidal exchange through 5 inlets that separate these islands (Fig. 1). The gulf-side shorelines of the islands are comprised entirely of sandy beaches. The inlets are a mixture of natural sand and anthropogenically hardened shorelines.

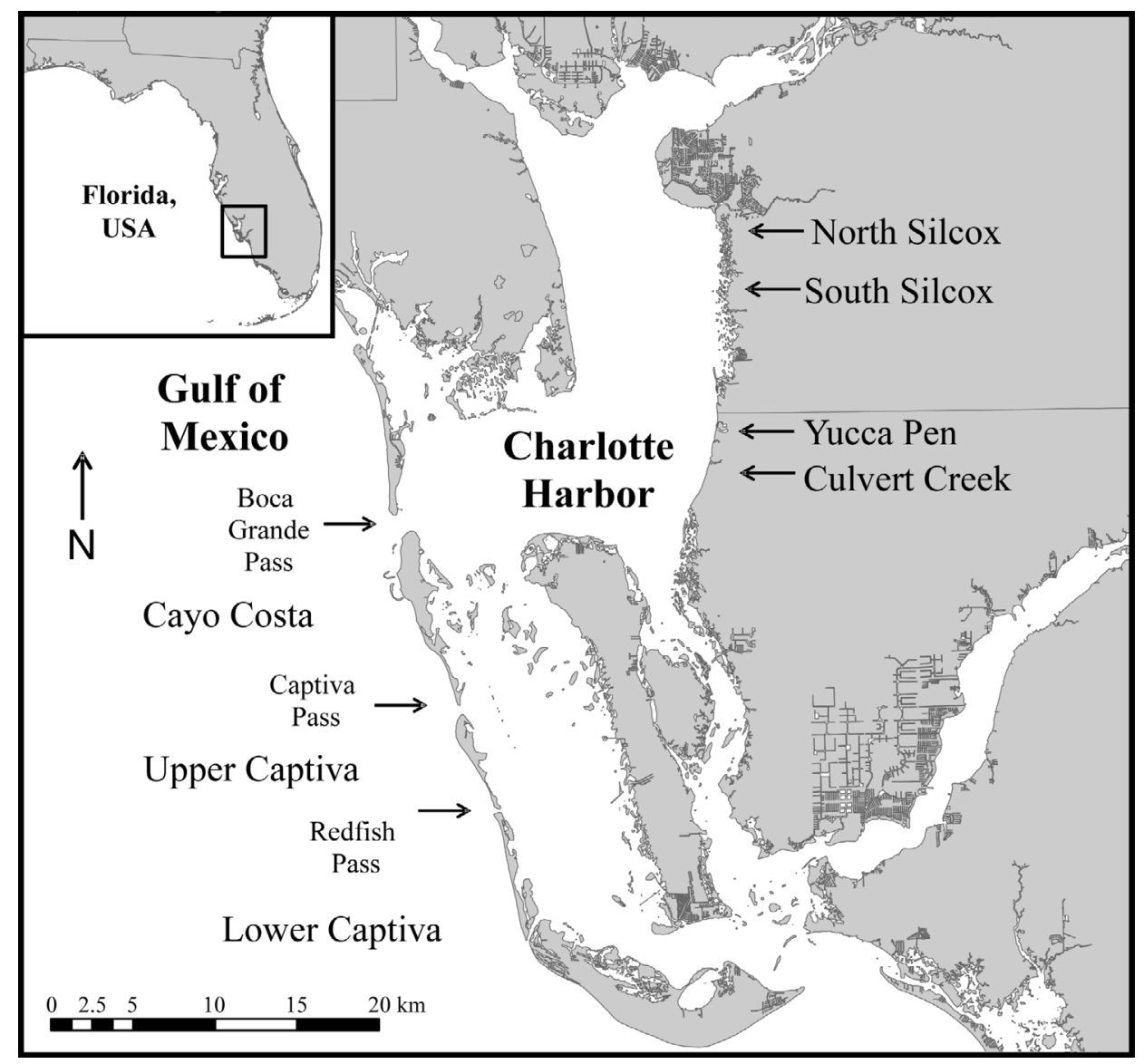

Fig. 1. Southwest Florida, USA. Capture-recapture in spawning adult common snook Centropomus undecimalis habitat occurred along barrier island beaches from the northern end of Cayo Costa (Boca Grande Pass) to the southern end of Lower Captiva (Blind Pass). Capture-resighting in juvenile common snook habitat occurred in 4 mangrove creeks (North Silcox to Culvert Creek) on Charlotte Harbor's eastern shoreline 


\section{Focal species}

The common snook (hereafter referred to as 'snook') is a tropical and subtropical, estuarine-dependent, euryhaline species. Insufficient information exists on life history linkages, but enough is known to allow targeted effort at specific ontogenetic stages. Snook are protandrous hermaphrodites (Muller \& Taylor 2006) that congregate in high-salinity environments to broadcast spawn during summer (Chapman et al. 1978, Peters et al. 1998). Typical spawning grounds are passes that connect estuaries and ocean waters, beaches, and perhaps offshore reefs (Taylor et al. 1998, Adams et al. 2011).

Following spawning, the planktonic larval stage lasts 2 wk (Peters et al. 1998). In Charlotte Harbor, Florida, post-settlement snook $(<20 \mathrm{~mm}$ standard length, SL) are first captured in tidal mangrove creeks in mid-June (A.J. Adams unpubl. data). Juveniles reach or exceed 150 to $180 \mathrm{~mm}$ by age-1, and remain abundant in or near creek habitats yearround until $\sim 300 \mathrm{~mm}$ (age-2; Taylor et al. 2000, Stevens et al. 2007), when they enter the adult population. Adults use open estuarine and nearshore habitats from spring through fall, and can overwinter in riverine or creek habitats (Blewett et al. 2009) where they cannibalize juveniles (Adams \& Wolfe 2006). Snook in Florida can live for $>20 \mathrm{yr}$, but 1 to 7 yr olds are most common (Taylor et al. 2000).

\section{Juvenile habitat}

From June 2004 through April 2011, we studied juvenile snook in 4 red mangrove Rhizophora mangle-fringed, tidal, estuarine creeks, each $\sim 1.6 \mathrm{~km}$ long, on the eastern shoreline of Charlotte Harbor (Fig. 1). The study creeks varied in width from 2 to $10 \mathrm{~m}$ in narrow passes to $>60 \mathrm{~m}$ in wider bays. Depths were shallow with maximum depth ranging from 0.5 to $2.5 \mathrm{~m}$ in narrow passes and from $<0.5$ to $1.0 \mathrm{~m}$ in bays. Approximately $0.75 \mathrm{~km}$ of flooded mangroves separated the mouths of the 2 northern creeks (South Silcox and North Silcox) from Charlotte Harbor. The 2 southern creeks (Yucca Pen and Culvert Creek) drained directly into Charlotte Harbor, and the creek mouths were separated by $1.4 \mathrm{~km}$ of mangrove shoreline. The northern and southern creeks were separated by 10 to $12 \mathrm{~km}$ of mangrove shoreline (Fig. 1).

We primarily captured juveniles $(<320 \mathrm{~mm}$ SL, McMichael et al. 1989, Stevens et al. 2007) with a center bag seine net $(30.5 \times 1.8 \mathrm{~m}, 6.3 \mathrm{~mm}$ mesh), but occasionally used a smaller seine $(21 \times 1.2 \mathrm{~m}, 3.1 \mathrm{~mm}$ mesh) or hook and line. Peak sampling months were October through April following summer spawning (Peters et al. 1998, Taylor et al. 1998). After capture, we scanned all fish with a handheld passive integrated transponder (PIT) tag reader (Allflex ${ }^{\circledR}$ model no. RS601), documented recaptures, and measured $\mathrm{SL}$ to the nearest millimeter. We marked juvenile snook $>120 \mathrm{~mm}$ and $<320 \mathrm{~mm}$ SL with uniquely coded half-duplex (HDX) PIT tags (23 mm length $x$ $3.4 \mathrm{~mm}$ diameter, $0.6 \mathrm{~g}$ in air; TIRFID S-2000, Texas Instruments). Snook >120 mm SL showed $100 \%$ tag retention with no mortality (Adams et al. 2006a), and snook >320 mm SL were no longer considered juveniles (McMichael et al. 1989, Stevens et al. 2007). We inserted PIT tags into the abdominal cavity of unmarked fish through a $3 \mathrm{~mm}$ incision posterior and ventral to the pectoral fin. Since the reading unit powers the tag, the resulting lifespan of the tag exceeds that of the study subject.

\section{Autonomous antennae}

We resighted marked snook with autonomous PIT tag antennae. From 2004 through November 2008, we evaluated the efficacy of this approach with 2 antennae (Adams et al. 2006a). From June to November 2008, 9 additional antennae were constructed, resulting in antenna placement in the lower, middle, and upper strata of each of the 4 creeks with the exception of Yucca Pen upper (due to antenna failure and financial constraints; Barbour et al. 2011). Antennae functioned continuously and resighted snook (fish were not physically recaptured) as marked individuals swam past an antenna. We fully described antennae methodology elsewhere (Adams et al. 2006a, Barbour et al. 2011, 2012).

\section{Juvenile habitat use}

We marked juvenile snook from June 2004 to January 2011. We defined 'marking years' as starting in or after October, and ending in or before August, due to summer spawning (most marking years began in November and ended in April). We analyzed 3 aspects of juvenile habitat use during the 3 marking years following antennae deployment (November 2008 to April 2011): home range size, intra-annual emigration, and inter-annual site fidelity.

We quantified home range size (Kramer \& Chapman 1999) by using resighting by multiple antennae 
as a proxy for movement. We limited this analysis to movement within an individual's marking year. Since we placed antennae approximately every $0.5 \mathrm{~km}$, resighting an individual snook by 2 antennae represented a minimum movement of $0.5 \mathrm{~km}$.

We quantified intra-annual emigration as occurring any time an individual was detected outside its marking creek during its marking year. We identified all emigrants as either temporary (emigrants that subsequently returned to their original creek) or permanent (emigrants that did not return).

We examined inter-annual site fidelity by quantifying the number of juveniles resighted inside versus outside their marking creek in the year after marking. A chi-squared contingency test was used to test whether emigration rate varied by creek and year. Due to a large juvenile home range size, we next examined fidelity to creek pairs (North and South Silcox versus Yucca Pen and Culvert Creek) with Fisher's Exact test (due to the high incidence of expected values $<5$ ).

\section{Adult spawning habitat}

We conducted mark-recapture of adult snook on Gulf of Mexico barrier islands during 4 spawning seasons (typically May through September) from May 2007 to August 2010 (Adams et al. 2009, 2011). We sampled adults with 3 seine nets $(91.4 \times$ $2.4 \mathrm{~m}, 19.1 \mathrm{~mm}$ mesh; $182.9 \times 2.4 \mathrm{~m}, 15.0 \mathrm{~mm}$ mesh; $152.4 \times 2.4 \mathrm{~m}, 19.1 \mathrm{~mm}$ mesh) along beaches of 3 islands: Cayo Costa (12.4 km long), Upper Captiva $(6.8 \mathrm{~km})$, and Lower Captiva (8.9 km; Fig. 1; see Adams et al. 2009). We scanned all snook for PIT tags after capture and marked adult snook with $23 \mathrm{~mm}$ PIT tags (e.g. Boucek \& Adams 2011), recording length and position (latitude and longitude) for each fish.

To determine spatial distribution of adult snook on each island, we plotted the locations of all snook (marked and recaptured) per $200 \mathrm{~m}$ of linear shoreline with ESRI ArcGIS. We then calculated the shortest shoreline distance between each mark and recapture position to investigate 3 aspects of movement and spawning area site fidelity. (1) To determine whether movement differed by island, distances (m) between mark and recapture were pooled across years by island, square-root transformed, and analyzed with a 1-way analysis of variance supported by a Tukey post hoc test. (2) We determined whether movement differed based on whether fish were recaptured in their marking year or in subsequent years. (3) Distance data for fish recaptured more than once were examined with a paired $t$-test (with Bonferroni adjusted probability of 0.05 ) to determine whether recapture distance differed during subsequent recaptures.

\section{Habitat linkages}

Since we marked juveniles and adults with PIT tags, we were able to examine recapture and resighting data to measure exchange between juvenile and adult habitats. We used PIT tag antennae to resight adults (marked from May 2007 to August 2010) that moved into juvenile habitat, and we used seine nets to recapture juveniles (marked from June 2004 to February 2010) that moved to summer spawning grounds.

\section{Severe cold event}

On 2 January 2010, a severe cold front created abnormally cold conditions for $13 \mathrm{~d}$. Charlotte Harbor water temperatures dropped from $18^{\circ} \mathrm{C}$ on 1 January to $12^{\circ} \mathrm{C}$ by 6 January, and remained $<12^{\circ} \mathrm{C}$ through 16 January, well below the average winter water temperature of $21^{\circ} \mathrm{C}$ for the estuary and below the lethal thermal threshold of common snook $\left(12.5^{\circ} \mathrm{C}\right.$, Shafland \& Foote 1983) for at least $10 \mathrm{~d}$ (Adams et al. 2012).

We estimated monthly apparent survival of juveniles $(\phi=1-$ mortality + emigration) from October through April for 3 marking years (2008-09, 2009-10, and 2010-11). For each year, we collapsed antennae resightings into monthly bins, with marked fish classified as ' 1 ' if resighted and ' 0 ' if not. We allowed $\phi$ and capture probability to be timedependent with respect to month and marking year. For adults, we combined marking (seine netting) and recapture (seine netting and recreational angling) information from spawning grounds. Capture histories were constructed on a yearly basis $(2007,2008$, 2009,2010 ), with fish being assigned a ' 1 ' in spawning seasons (May through September) during which they were marked or recaptured, and a ' 0 ' in seasons they were not seen. Capture probability was kept constant, as the same sampling methods were used each year, and $\phi$ was allowed to vary between spawning seasons. We estimated $\phi$ with the Cormack-Jolly-Seber survival model in Program MARK (White \& Burnham 1999, Adams et al. 2006a) for both juveniles and adults. 


\section{RESULTS}

\section{Juvenile habitat}

We marked 2191 juveniles between June 2004 and October 2008 (prior to deployment of the antennae array) and 1924 between November 2008 and January 2011. Snook <320 mm SL dominated catches, and catches consisted of 2 approximated size classes (SC) (Fig. 2, SC1: 120-200 mm SL and SC2: 201-320 mm SL). The 11 autonomous PIT tag antennae logged 536279 total resightings of 2087 uniquely marked snook (adults and juveniles) from November 2008 to April 2011.

Home range size. Home range size increased with increasing body size (Table 1). Overall, a majority $(63.1 \%)$ of the 1924 juveniles marked since November 2008 crossed at least 2 antennae, and $28.2 \%$ crossed at least 3 within their marking year (Table 1). Thus, a minimum estimate of juvenile snook home range size (distance moved) is $0.5 \mathrm{~km}$. Additionally, $8.7 \%$ of juveniles crossed at least 4 antennae, the fourth located in another creek, indicating that a substantial portion of marked juveniles traveled $>1.0 \mathrm{~km}$.

Intra-annual site fidelity. Emigration increased with fish size: an equal number of snook in both size classes emigrated from the creek in which they were tagged (177 SC1 and $186 \mathrm{SC} 2$ ) despite marking 40\% more SC1 snook (Fig. 2). In total, $19.8 \%$ of 1924 juveniles emigrated, with similar levels of temporary $(40 \%)$ and permanent (60\%) emigration. Similarly to home range size, these are conservative estimates since antennae functioned in a spatially limited region.

Inter-annual site fidelity. When examined by creek, there was no evidence for inter-annual fidelity $(\mathrm{p}=$ 0.1693 ; df $=4 ; \chi^{2}=3.64$; Table 2a). However, significant evidence existed when using paired creeks to account for home range size (Fisher's Exact test: $\mathrm{p}=$ 0.0036; Table 2b). Thus, inter-annual site fidelity occurs on a scale similar to that of the juvenile home range, with snook preferentially returning to their juvenile habitats.

\section{Adult habitat}

During this study, we marked 3304 adults in spawning habitat (Fig. 2). Although sampling effort was similar on all islands, more snook were marked on Cayo Costa than Upper or Lower Captiva. In total, 186 recaptures were made during the study (5.63\%), and sizes of marked and recaptured fish were similar

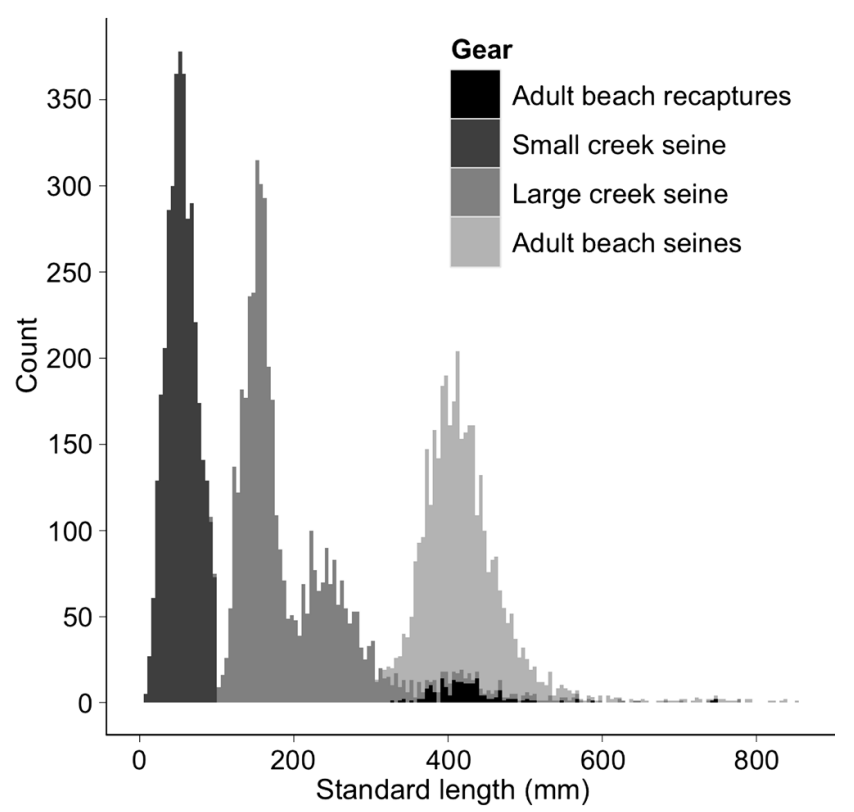

Fig. 2. Centropomus undecimalis. Standard lengths (mm) of all common snook captured during this study in Charlotte Harbor, Florida, USA. Snook caught using a small-mesh (n = $3715)$ and large-mesh $(n=4370)$ center bag seine in juvenile habitat (mangrove creeks), or 3 large center bag seines in spawning habitat (barrier island beaches: $\mathrm{n}=3316$ ). Marked juvenile snook were captured with the large creek seine

Table 1. Centropomus undecimalis. Number and percent of juvenile snook marked from November 2008 to January 2011 (1425 size class 1 [SC 1] and 499 SC2) and resighted from November 2008 to April 2011, that were resighted by at least the given number of antennae. For this analysis we limited resightings to instances within an individual's marking year (October through August). Antennae were placed approximately every $0.5 \mathrm{~km}$ in each creek, so resighting by 2 antennae represents a minimum movement of $0.5 \mathrm{~km}$

\begin{tabular}{|lcccc|}
\hline No. of antennae & Number SC1 & $\%$ & Number SC2 & $\%$ \\
\hline 2 & 836 & 58.7 & 379 & 80.0 \\
3 & 321 & 22.5 & 222 & 44.5 \\
4 & 83 & 5.8 & 84 & 16.8 \\
5 & 39 & 2.7 & 48 & 9.6 \\
6 & 3 & 0.2 & 5 & 1.0 \\
7 & 0 & 0.0 & 2 & 0.4 \\
\hline
\end{tabular}

(Fig. 2). Of the 186 total recaptures, 171 were from fish recaptured once and 11 were from fish recaptured multiple times.

Snook capture locations revealed clumped distributions, indicating propensity of snook to aggregate at particular locations (Fig. 4 in Adams et al. 2011). Over the 4 yr study, 166 of the 171 unique recaptures $(97.08 \%)$ occurred on the same island where they were marked, supporting a pattern of spawning loca- 
Table 2. Centropomus undecimalis. Quantitative description of inter-annual site fidelity by juvenile snook marked in 4 mangrove creeks. Table shows the marking year $(1=$ October 2007 to July 2008; 2 = November 2008 to April 2009; $3=$ November 2009 to February 2010). Total number of antennae resightings of uniquely marked individuals in the subsequent years were (1) 20617 , (2) 22632 , (3) 11348. Numbers of resightings of unique individuals were grouped by (a) creek or (b) north vs. south region

\begin{tabular}{|lccc|}
\hline \multirow{4}{*}{ Parameter } & \multicolumn{3}{c}{ Marking year } \\
& 1 & 2 & 3 \\
\hline (a) By marking creek & & & \\
Fish marked & 315 & 851 & 594 \\
Fish resighted & 32 & 65 & 35 \\
Inside creek & 6 & 14 & 11 \\
Outside of creek & 31 & 31 & 28 \\
Inside and outside of creek & 67 & 109 & 65 \\
(b) By marking region (north vs. south) & & \\
Inside region & 1 & 1 & 7 \\
Outside of region & 1 & 0 & 2 \\
Inside and outside of region & & & \\
\hline
\end{tabular}

tion site fidelity. Of the recaptures, 107 occurred in the same year as marking, and 79 occurred 1 or 2 yr after marking. Four of the 5 snook recaptured on a different island were originally marked on Upper Captiva, the shortest barrier island, as well as the middle of the 3 islands (Fig. 1).

Distance between mark and recapture locations differed by island (ANOVA p $<0.01$, df $=170, F=$ 6.993): mean $\pm \mathrm{SE}=1773.7 \pm 161.0 \mathrm{~m}$ for Cayo Costa; $871.9 \pm 75.3 \mathrm{~m}$ for Upper Captiva; and $1377.6 \pm$ $334.5 \mathrm{~m}$ for Lower Captiva, suggesting that home range size of adults on spawning grounds was $<2 \mathrm{~km}$. Distance between mark and recapture locations did not depend upon fish being recaptured in their marking year or in subsequent years (Fig. 2a in Adams et al. 2011). However, fish recaptured twice were recaptured at a greater distance from the marking location at the second recapture $(t=-3.558$, Bonferroni adjusted $\mathrm{p}<0.05, \mathrm{df}=10$ ).

\section{Habitat linkages}

Of 3642 juveniles marked before cessation of spawning habitat sampling, we recaptured 4 (0.1\%) on gulf shoreline beaches as adults. Each fish was recaptured once, with a mean of $838 \mathrm{~d}$ and a range of 461 to 1207 d between marking and recapture. We recaptured 3 fish on Cayo Costa and 1 fish on Upper Captiva. Two fish were marked in Culvert Creek, 1 in South Silcox, and 1 in North Silcox.
Similarly, of 3304 adult snook marked on Gulf of Mexico beaches, antennae in mangrove creeks detected $5(0.15 \%)$ in the juvenile study creeks. Four were marked on Cayo Costa and 1 on Upper Captiva. Resightings of adults in the juvenile study creeks primarily occurred between October and April, but 1 individual was also resighted during summer. Two adults were detected only in South Silcox, 1 in Culvert Creek, and 1 in Yucca Pen. These 4 fish were resighted for $1 \mathrm{~d}$ only. The fifth fish was detected in all 4 creeks, and these resightings occurred over the course of a year.

\section{Severe cold event}

Juveniles. The Cormack-Jolly-Seber maximum likelihood estimate for apparent survival $(\phi)$ during the January 2010 cold event was 0.55, which was 22.6 to $38.3 \%$ lower than other monthly maximum likelihood estimates during the $3 \mathrm{yr}$ of survival analysis (minimum $=0.71$, maximum $=0.89$; Fig. 3 ). Additionally, when examining $95 \%$ confidence intervals, $\phi$ during the cold event was significantly lower than every other monthly estimate.

Adults. The cold event did not influence patterns of site fidelity by adult snook on spawning grounds. However, $\phi$ after the cold event was sig-

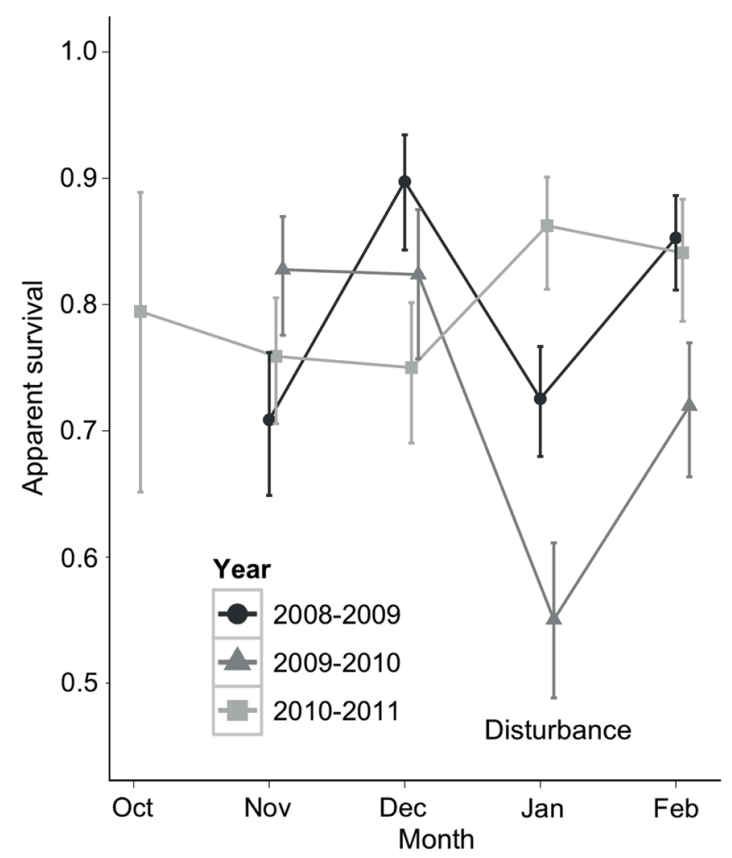

Fig. 3. Centropomus undecimalis. Monthly Cormack-JollySeber apparent survival estimates (with $95 \%$ CI) from 3 yr of capture-resighting data in juvenile common snook habitat (mangrove creeks) 
Table 3. Centropomus undecimalis. Total numbers of common snook captured during January through June of each year by the Florida Fish and Wildlife Conservation Commission Fisheries Independent Monitoring program for 4 estuaries

\begin{tabular}{|ccccc|}
\hline Year & $\begin{array}{c}\text { Tampa } \\
\text { Bay }\end{array}$ & $\begin{array}{c}\text { Charlotte } \\
\text { Harbor }\end{array}$ & $\begin{array}{c}\text { North Indian } \\
\text { River Lagoon }\end{array}$ & $\begin{array}{c}\text { South Indian } \\
\text { River Lagoon }\end{array}$ \\
\hline 2008 & 639 & 223 & 190 & 341 \\
2009 & 347 & 123 & 144 & 449 \\
2010 & 90 & 28 & 30 & 154 \\
\hline
\end{tabular}

nificantly lower than before. Apparent survival estimates were 0.45 between the 2007 and 2008 spawning seasons, and 0.65 between 2008 and 2009 (these values aligned with the mortality estimates used in the most recent snook stock assessment: Muller \& Taylor 2006, their Fig. 4.3.2.3). After the cold event, $\phi$ dropped to 0.01 as compared to 0.45 and 0.65 in the $2 \mathrm{yr}$ prior to the cold event. Declines in snook abundance were similar elsewhere in Florida (Table 3).

\section{DISCUSSION}

We have developed a better understanding of habitat use in 2 distinct portions of snook life history, which provides a foundation for examining connections between life stages, including spatial dynamics of fish-habitat interactions. For example, prior to this research, the level of site fidelity of adult common snook on spawning grounds was unknown. Such fidelity implies some level of metapopulation structure induced by spawning segregation, and connections between spawning locations and particular juvenile habitats (the latter because, on average, estuary currents will carry larvae to a particular area). Given this new understanding, the focus of future research has changed to address these issues, which had not previously been considered for common snook.

Similarly, we found that the contribution of emigration to declines in apparent survival of juveniles was significant, which requires a reexamination of the general assumption in research on juvenile fishes that declines in abundance at a sample site provide an estimate of mortality. Clearly, emigration is an important factor in local declines that requires revision of juvenile survival estimates for common snook, and likely for other species that exhibit amonghabitat mobility (e.g. 'ontogenetic shifters' in Adams et al. 2006b). As with adults, this finding requires a revision of future research focus to address issues such as the effects of habitat contiguity on movement and survival.

\section{Site fidelity \\ Juveniles}

Site fidelity by juvenile snook likely reflects a tradeoff between growth and survival. Because different habitats vary in the quantity and quality of food, as well as refuge and predation potential, there are tradeoffs between achieving a high growth rate and survival. Under the ideal free distribution theory (Fretwell \& Lucas 1970), individuals will choose to use a habitat that maximizes resource use of individuals, and will change habitats when per capita resource availability increases in one habitat relative to another. Thus, juvenile snook may use poor-quality habitats when densities are high in high-quality habitats, but such poor-quality habitats may not be used when densities are low in better habitats. Dahlgren \& Eggleston (2000), for example, found ontogenetic habitat shifts by juvenile Nassau groupers to be consistent with the predictions that ontogenetic habitat shifts minimize the ratio of mortality risk to growth rate.

The emigration rate for juvenile snook was comparable to other species (Frederick 1997). Emigration may be due to a search for habitat with maximum resource potential and minimal predation risk, or the need for a habitat mosaic that provides multiple resource pools (Sheaves 2009). The expansion of home range with increasing size supports the use of a habitat mosaic, or may be associated with assessment of habitat quality. As juvenile snook grow and their probability of mortality declines, their home range size and movement rates increase as they use alternative habitats to a greater extent, eventually losing their reliance on mangrove creeks.

Although intra-annual juvenile movement was more common than previously assumed, juveniles exhibited inter-annual regional site fidelity. Juveniles likely exhibited inter-annual site fidelity because the habitats had been previously identified as high quality, or due to the risk of movements substantially larger than their home range size. Due to the size of their home range $(\geq 0.5 \mathrm{~km})$, an effective juvenile snook nursery habitat would require relatively large tracts of contiguous suitable habitat. 


\section{Adults}

Site fidelity for adults poses advantages and disadvantages. There is a benefit to returning to a spawning location if reproductive success at that location is higher than at other locations. For example, mortality from predators may be lower, more or better potential mates may be present, larval survival may be higher, and currents may transport larvae to higher-quality nursery habitats (i.e. high quality nursery habitats = source, low quality nursery habitats = sink; e.g. Lipcius et al. 1997). However, spawning site fidelity may slow the recovery from disturbances. For example, spawning segregation may have led to the slower than expected response of Atlantic cod to overfishing, because site fidelity impedes recolonization of spawning grounds (Robichaud \& Rose 2001). Similarly, Colin (1992) determined that Nassau grouper traveled up to $100 \mathrm{~km}$ to reach a spawning site, which helps explain the large spatial scale decline of Nassau grouper when spawning sites are targeted by fishing.

\section{Habitat linkages}

Connectivity between juvenile and adult marine fish habitats has been difficult to establish through mark-recapture studies (Thorrold et al. 2001). For example, Courtney et al. (2000) recovered only 49 coded wire tags from a marked population of several million salmon. Despite a high number of marks employed, multiple years of recapture, and a highly efficient telemetry array, we were only able to recapture or resight $0.1 \%$ of marked fish as moving between juvenile and adult habitats. Potential causes of low recapture were high mortality in the juvenile life stage, high fishing mortality, and high mortality from the severe cold event described herein. Given the inefficiency of physical recapture $(5.63 \%$ beach seine recapture) versus telemetry (Barbour et al. 2012) and the low number of remaining marked individuals after accounting for mortality, this example highlights challenges of quantifying ontogenetic connectivity with a mark-recapture approach.

Despite the difficulty of quantifying habitat linkages through mark-recapture, important information was gained to focus future examination of population segregation. Spawning segregation caused by adult fidelity to spawning grounds suggests a metapopulation structure (Hanski \& Gilpin 1997, Smedbol \& Stephenson 2001), and the inter-life stage recaptures in this study imply that this metapopulation structure may be extended to the entire population by juve- nile-to-adult as well as adult-to-juvenile habitat connections. For example, all of the inter-life stage recaptures/resightings involved movement between the studied juvenile habitats and the 2 closest spawning ground islands. Such connectivity, coupled with site fidelity, may induce a metapopulation structure that requires an estuary-specific rather than regional management approach, has implications for prioritization of habitat conservation and restoration, and may influence the ability of local populations to respond to disturbances.

\section{Severe cold event}

Infrequent, severe cold disturbances recur in subtropical southwest Florida, with published reports of cold-related fish kills from as early as the 1800's (e.g. Storey \& Gudger 1936, Galloway 1941). Although different life stages may show different responses to disturbances, in part based on characteristics specific to their life stage (e.g. due to physiology, habitat use), we found evidence for major disturbance effects on both adult and juvenile life stages: maximum likelihood estimates of apparent survival decreased by 97.8 to $98.5 \%$ in adults and by 22.6 to $38.3 \%$ in juveniles. This analysis shows independent declines in apparent survival in both habitats (i.e. life stages) that were unprecedented in multiple years.

We suggest 2 possible causes for the decline in adult and juvenile snook apparent survival: lethal and sub-lethal effects. Lethal effects, particularly mortality from a cessation of cellular functioning (Somero 1995) when water temperature dropped below the study subject's lower thermal limit for $10 \mathrm{~d}$, were likely the primary causes of the declines. In the sub-lethal effects scenario, surviving adult snook used available resources to counter stress-related effects (Schreck et al. 2001), leaving fewer resources to allocate to spawning (McCullough et al. 2001), resulting in population-level implications by reducing the population's fecundity.

A sub-lethal response by juvenile snook would occur by emigration from the nursery habitat mosaic in search of thermal refugia. Such movement, however, could increase predation susceptibility (Barbour et al. in press). Although we did document high rates of juvenile emigration throughout the entirety of the study, we did not document an increase in emigration during the cold event. Moreover, juvenile emigrants would have to find alternative suitable nursery habitats following the disturbance since we did not document an increase in temporary emigration. 


\section{CONCLUSIONS AND FUTURE RESEARCH}

In the constricted juvenile habitat, application of PIT tag telemetry allowed for a high resighting rate and provided new information that traditional physical recapture or more expensive biologging techniques would be unable to yield (Barbour et al. 2012). The demonstration of high levels of site fidelity by both juveniles and adults changes our understanding of habitat use, and implies a metapopulation structure with multi-life stage connectivity and location- and habitat-specific characteristics. Since habitat loss and degradation are among the top causes of fish population declines worldwide, common snook may be especially at risk due to these characteristics. Future research on habitat linkages should incorporate additional methods to augment biologging, such as otolith microchemistry (e.g. Gillanders 2005) and genetic analysis (e.g. Bradbury et al. 2008). Improved knowledge of connectivity would allow a better assessment of the nursery value of the juvenile habitats (Beck et al. 2001, Adams et al. 2006b), and help determine whether a metapopulation structure exists (Hanski \& Gilpin 1997, Smedbol \& Stephenson 2001), allowing for adaptable regional management plans and proper prioritization of habitat conservation. Overall, the improved understanding of common snook ontogeny will contribute to future management of the western Florida fishery, which has been closed to harvest since the 2010 cold event, and will form a basis by which to evaluate the feasibility of juvenile hatchery enhancement.

Acknowledgements. This publication was supported by grants from the National Sea Grant College Program of the US Department of Commerce's National Oceanic and Atmospheric Administration (NOAA), grant no. NA06OAR4170014 to A.J.A.; Charlotte Harbor National Estuary Program to A.J.A.; Southwest Florida Water Management District to A.J.A.; Mote Scientific Foundation to A.J.A.; a National Science Foundation (NSF) Graduate Research Fellowship under grant no. DGE-0802270 to A.B.B., and NSF REU grants to J. Gelsleichter and B. Kirkpatrik. We thank D.R. Gulnac and D.K. Gulnac for facilities, S. Anderson, T. Barker, N. Barkowski, R. Boucek, A. Chicone, M. Hammond, J. Hill, J. King, B. Kurth, M. McGraw, J. Millar, C. Murray, C. Samoray, S. Yess, T. Yess, J. Zehnder, and numerous volunteers for field assistance, and M. Gil, J. Kerns and K. Wilson for assistance with the manuscript. Marking was conducted according to standards set by the Mote Marine Laboratory Institutional Animal Care and Use Committee (IACUC permit no. 0704aa1). The views expressed are those of the authors and do not necessarily reflect the view of these organizations.

\section{LITERATURE CITED}

Adams AJ, Hill JE, Kurth BN, Barbour AB (2012) Effects of a severe cold event on a subtropical, estuarine-dependent fish. Gulf Caribb Res 24:13-21

Adams AJ, Wolfe RK (2006) Cannibalism of juveniles by adult common snook (Centropomus undecimalis). Gulf Mex Sci 24:11-13

> Adams AJ, Wolfe RK, Pine WE III, Thornton BL (2006a) Efficacy of PIT marks and an autonomous antenna system to study the juvenile life stage of an estuarine-dependent fish. Estuaries 29:311-317

Adams AJ, Dahlgren C, Kellison GT, Kendall MS and others (2006b) Nursery function of tropical back-reef systems. Mar Ecol Prog Ser 318:287-301

Adams AJ, Wolfe RK, Barkowski N, Overcash D (2009) Fidelity to spawning grounds by a catadromous fish, Centropomus undecimalis. Mar Ecol Prog Ser 389:213-222

Adams AJ, Hill JE, Samoray C (2011) Characteristics of spawning ground fidelity by a diadromous fish: a multiyear perspective. Environ Biol Fishes 92:403-411

Barbour AB, Adams AJ, Behringer DC, Yess T, Wolfe RK (2011) PIT tag antennae arrays as fishery monitoring tools in tropical environments. Proc Gulf Caribb Fish Inst 63:118-124

Barbour AB, Boucek RE, Adams AJ (in press) Effect of pulsed gastric lavage on apparent survival of a juvenile fish in a natural system. J Exp Mar Biol Ecol

Barbour AB, Adams AJ, Yess T, Behringer DC, Wolfe RK (2012) Comparison and cost-benefit analysis of PIT tag antennae resighting and seine-net recapture techniques for survival analysis of an estuarine-dependent fish. Fish Res 121-122:153-160

Beck MW, Heck KL, Able KW, Childers DL and others (2001) The identification, conservation, and management of estuarine and marine nurseries for fish and invertebrates. Bioscience 51:633-641

Blewett DA, Stevens PW, Champeau TR, Taylor RC (2009) Use of rivers by common snook (Centropomus undecimalis) in southwest Florida: a first step in addressing the overwintering paradigm. Fla Sci 72:310-324

Bolden SK (2000) Long-distance movement of a Nassau grouper (Epinephelus striatus) to a spawning aggregation in the central Bahamas. Fish Bull 98:642-645

> Boucek RE, Adams AJ (2011) Comparison of retention rates for three mark types in common snook, Centropomus undecimalis. N Am J Fish Manag 31:693-699

> Bradbury IR, Campana SE, Bentzen P (2008) Low genetic connectivity in an estuarine fish with pelagic larvae. Can J Fish Aquat Sci 65:147-158

Chapman P, Horel G, Fish W, Jones K, Spicola J (1978) Artificial culture of snook, Rookery Bay, 1977, Job Number 2: induced spawning and fry culture. Annual Report on Sportfish Introductions. Florida Games and Fresh Water Fish Commission, St Petersburg, FL

> Colin PL (1992) Reproduction of the Nassau grouper, Epinephelus striatus (Pisces: Serranidae) and its relationship to environmental conditions. Environ Biol Fishes 34: 357-377

> Courtney DL, Mortensen DG, Orsi JA, Munk KM (2000) Origin of juvenile Pacific salmon recovered from coastal southeastern Alaska identified by otolith thermal marks and coded wire tags. Fish Res 46:267-278

Cowan JH Jr, Grimes CB, Patterson WF III, Walters CJ and others (2010) Red snapper management in the Gulf of 
Mexico: science- or faith-based? Rev Fish Biol Fish 21: 187-204

Dahlgren CP, Eggleston DB (2000) Ecological processes underlying ontogenetic habitat shifts in a coral reef fish. Ecology 81:2227-2240

Eggleston DB (1995) Recruitment in Nassau grouper Epinephelus striatus: post-settlement abundance, microhabitat features, and ontogenetic habitat shifts. Mar Ecol Prog Ser 124:9-22

Frederick JL (1997) Post-settlement movement of coral reef fishes and bias in survival estimates. Mar Ecol Prog Ser 150:65-74

Fretwell SB, Lucas HL Jr (1970) On territorial behavior and other factors influencing habitat distribution in birds. Acta Biotheor 19:16-36

Galloway JC (1941) Lethal effect of the cold winter of 1939-40 on marine fishes at Key West, Florida. Copeia 1941:118-119

> Gillanders BM (2005) Using elemental chemistry of fish otoliths to determine connectivity between estuarine and coastal habitats. Estuar Coast Shelf Sci 64:47-57

Grover JJ, Eggleston DB, Shenker JM (1998) Transition from pelagic to demersal phase in early-juvenile Nassau grouper, Epinephelus striatus: pigmentation, squamation, and ontogeny of diet. Bull Mar Sci 62:97-113

Hammett KM (1990) Land use, water use, streamflow, and water quality characteristics of the Charlotte Harbor inflow area, Florida. US Geol Surv Water Supply Pap 2359-A. USGS, St. Petersburg, FL

Hanski IA, Gilpin ME (1997) Metapopulation biology: ecology, genetics and evolution. Academic Press, New York, NY

Herzka SZ, Holt SA, Holt GJ (2002) Characterization of settlement patterns of red drum Sciaenops ocellatus larvae to estuarine nursery habitat: a stable isotope approach. Mar Ecol Prog Ser 226:143-156

Kramer DL, Chapman MR (1999) Implications of fish home range size and relocation for marine reserve function. Environ Biol Fishes 55:65-79

Lipcius RN, Stockhausen WT, Eggleston DB, Marshall KS Jr, Hickey B (1997) Hydrodynamic decoupling of recruitment, habitat quality and adult abundance in the Caribbean spiny lobster: source-sink dynamics? Mar Freshw Res 48:807-816

McCullough D, Spalding S, Sturdevant D, Hicks M (2001) Summary of technical literature examining the physiological effects of temperature on salmonids. EPA-910-D01-005. US Environmental Protection Agency. Available at http://yosemite.epa.gov/R10/WATER.NSF/6cb1a1df2 c49e4968825688200712cb7/5eb9e547ee9e111f88256a 03005bd665/\$FILE/Paper\%205-Literature\%20Temp.pdf

McMichael RH Jr, Peters KM, Parsons GR (1989) Early life history of the snook Centropomus undecimalis, in Tampa Bay, Florida. Northeast Gulf Sci 10:113-125

Muller RG, Taylor RG (2006) The 2005 stock assessment update of common snook, Centropomus undecimalis. Report to the Florida Marine Fisheries Commission, Florida Fish and Wildlife Conservation Commission,
IHR 20006-003. Florida Marine Research Institute, St. Petersburg, FL

Peters KM, Matheson RE Jr, Taylor RG (1998) Reproduction and early life history of common snook, Centropomus undecimalis (Bloch), in Florida. Bull Mar Sci 62:509-529

Robichaud D, Rose GA (2001) Multiyear homing of Atlantic cod to a spawning ground. Can J Fish Aquat Sci 58: 2325-2329

Sargent FJ, Leary TJ, Crewz DW, Kruer CR (1995) Scarring of Florida's seagrasses: assessment and management options. FMRI Tech Rep TR-1. Florida Marine Research Institute, St. Petersburg, FL

Schreck CB, Contreras-Sanchez W, Fitzpatrick MS (2001) Effects of stress on fish reproduction, gamete quality, and progeny. Aquaculture 197:3-24

Shafland PL, Foote KJ (1983) A lower lethal temperature for fingerling snook (Centropomus undecimalis). Northeast Gulf Sci 6:175-177

Sheaves M (2009) Consequences of ecological connectivity: the coastal ecosystem mosaic. Mar Ecol Prog Ser 391: $107-115$

Shenker JM, Cowie-Mojica E, Crabtree RE, Patterson HM, Stevens C, Yakubik K (2002) Recruitment of tarpon (Megalops atlanticus) leptocephali into the Indian River Lagoon, Florida. Contrib Mar Sci 35:55-69

Shulman MJ, Ogden JC (1987) What controls tropical reef fish populations: recruitment or benthic mortality? An example in the Caribbean reef fish Haemulon flavolineatum. Mar Ecol Prog Ser 39:233-242

Smedbol RK, Stephenson R (2001) The importance of managing within-species diversity in cod and herring fisheries of the north-western Atlantic. J Fish Biol 59: $109-128$

Somero GN (1995) Proteins and temperature. Annu Rev Physiol 57:43-68

Stevens PW, Blewett DA, Poulakis GR (2007) Variable habitat use by juvenile common snook, Centropomus undecimalis (Pisces: Centropomidae): applying a life-history model in a southwest Florida estuary. Bull Mar Sci 80: 83-108

> Storey M, Gudger EW (1936) Mortality of fishes due to cold at Sanibel Island, Florida, 1886-1936. Ecology 17: 640-648

Taylor RG, Grier HJ, Whittington JA (1998) Spawning rhythms of common snook in Florida. J Fish Biol 53: 502-520

Taylor RG, Whittington JA, Grier HJ, Crabtree RE (2000) Age, growth, maturation, and protandric sex reversal in common snook, Centropomus undecimalis, from the east and west coasts of South Florida. Fish Bull 98:612-624

Thorrold SR, Latkoczy C, Swart PK, Jones CM (2001) Natal homing in a marine fish metapopulation. Science 291: 297-299

White GC, Burnham KP (1999) Program MARK: survival estimation from populations of marked animals. Bird Study 46:S120-S139

Proofs received from author(s): April 30, 2012 